\title{
Chapter 2 \\ Life Skills Education for Youth in Developing Countries: What Are They and Why Do They Matter?
}

\author{
Erin Murphy-Graham and Alison K. Cohen
}

\begin{abstract}
Drawing from a review of theoretical, methodological, and empirical literature on life skills from the fields of education, public health, psychology, economics, and international development, this paper attempts to clarify basic definitional and conceptual issues that relate to life skills education. It addresses the questions: (1) What are life skills, and how has the term emerged in academic and donor agency literature? And (2) What bodies of practice and research evidence converge in the rise of 'life skills' programming and increased interest in 'life skills' among thought leaders and donors in the field of international education? The paper identifies implications from this analysis to be considered in research and interventions that focus on life skills for adolescents, particularly in light of global efforts to improve the quality of education.
\end{abstract}

Keywords Life skills · Adolescents · International education · Quality education · Low-income countries

\section{Introduction: Clarifying the Muddy Waters of Life Skills Education}

'Life skills' is a popular concept in the field of education. One review of the literature on 'life skills' education found that there were as many definitions of life skills as there were global education actors and thought leaders (Dupuy \& Halvorsen, 2016). Non-governmental organizations and international aid agencies such as the UK Department for International Development (DFID), the United States Agency

E. Murphy-Graham $(\bowtie)$

University of California, Berkeley, Berkeley, CA, USA

e-mail: emurphy@berkeley.edu

A. K. Cohen

Epidemiology \& Biostatistics, School of Medicine, University of California, Berkeley, USA

(C) The Author(s) 2022

J. DeJaeghere, E. Murphy-Graham (eds.), Life Skills Education for Youth, Young

People and Learning Processes in School and Everyday Life 5,

https://doi.org/10.1007/978-3-030-85214-6_2 
for International Development (USAID), the World Bank, and UNICEF embrace the idea that education should prepare individuals both academically and with 'skills,' also referred to as 'life skills,' 'non-cognitive skills,' 'character skills' and/ or 'socio-emotional skills.' ${ }^{1}$ Acquiring 'skills' is commonly mentioned as a characteristic of quality education (e.g., Sayed \& Ahmed, 2015; Sustainable Development Goal Target 4.4; Tikly \& Barrett, 2011). The meanings and terminologies associated with the concept of life skills vary, and methods for systematically measuring and tracking changes in life skills are not well defined. While life skills might be a catchy phrase, specification of the cognitive, socio-emotional and behavioral learning outcomes is needed, particularly for researchers interested in examining how and if interventions can lead to improvements in people's lives.

Drawing from a review of theoretical, methodological, and empirical literature on life skills from the fields of education, public health, psychology, economics, and international development, this chapter attempts to clarify basic definitional and conceptual issues that relate to life skills education. It addresses the questions:

- What are life skills, and how has the term emerged and changed over time in academic and donor agency literature?

- What bodies of practice and research evidence converge in the rise of life skills programming and increased interest in life skills education for youth?

Based on our review of existing research and program/institutional documents, we identify distinct but overlapping discourse communities that use the term 'life skills' that have converged in the field of education. A discourse community is a group of people who share a set of basic values, assumptions, and goals, and use communication to achieve these goals (Swales, 1990). ${ }^{1}$ While there is some overlap in how these discourse communities conceptualize life skills, the goals of each of these are somewhat distinct, and therefore the ways in which they invoke 'life skills' varies. These discourse communities include the education community in which we situate ourselves and our concern with the quality of education, particularly in developing country contexts. Two more longstanding discourse communities, which indeed spill into the quality education community, include: (a) scholars and practitioners of public health and social work who are concerned with skills for 'prevention and protection;' and (b) economists, who have focused on 'labor market outcomes' and draw upon work in the field of psychology. We describe each of these discourse communities in greater detail, as well as the areas of overlap in how they use the term 'life skills' in their interventions and publications. After discussing the findings from our examination of 'life skills' in the academic and donor agency literature, we conclude by explaining how the capabilities approach to education, which explicitly links education with a social justice perspective and provides a wider set of outcomes from life skills education than offered by any

\footnotetext{
${ }^{1}$ We use the term "discourse community" rather than "field" or "discipline" because it also allows to capture the various actors working in educational settings, including non-governmental organizations, local education stakeholders, and the youth, facilitators, and community members that are engaged in life skills education programming around the world.
} 
single discourse community, can help inform future work on education and life skills for youth (Robeyns, 2017; Tikly \& Barrett, 2011; Walker, 2012).

\section{Skill as the Ability to Do Something Well}

Before proceeding, we explain what we mean by 'skill' and 'life skills,' although there is a great deal of variability in how these concepts are defined in the studies we review below. The terms 'skill' and 'competency' are commonly collapsed, but in the past the word 'skill' referred to the ability to undertake a task in the context of work and the skilled worker was trained (Taylor, 2005, pp. 201-18). Skill often focused on manual skills that involved both physical psychomotor abilities and mental cognitive abilities (Winterton et al., 2006). Very briefly defined, 'skill' refers to the ability, coming from one's knowledge, practice, and aptitude, to do something well.

The term 'cognitive skills' has traditionally been used to refer to processes that occur in the brain to learn to do something well. Cognitive skills are associated with activities such as problem solving, reasoning, thinking, assessing, concluding and include the mental processes of analysis, synthesis and evaluation (Westera, 2011, p. 77). More recent research has introduced the idea of 'embodied cognition' - that the brain is actually part of a broader system that involves perception and action as well (Shapiro, 2007). Performing tasks therefore requires a complex synergy between cognitive and bodily functions. Driving is an example that helps explain this synergy:

In skills training, substantial repetition, which allows learners to gradually improve their performance levels in terms of speed, precision and fluency, is usually involved. As a consequence, skills performance becomes more and more automated: experienced drivers, for example, are hardly aware of the complex cognitive tasks they perform, while their inexperienced counterparts must consciously think about almost any operation they carry out (Westera, 2011, p. 77).

Skills are connected with the accomplishment of specific tasks (driving, solving problems) and repetition is often required to improve performance. A combination of perceptual, cognitive and motor skills is involved in the demonstration of skilled performance. Training programs can provide opportunities to gain the knowledge and practice in specific domains that lead to skill mastery.

If we take the idea that a skill is the ability to do something well, then 'life skills,' in its broadest and most simplistic definition is to be able to do life well. But more commonly, it refers to skills that help a person through everyday tasks and to be active and engaged members of a community. 


\section{Review and Analysis of Life Skills Education}

To better understand how various actors in the field of international development education are engaging with the term 'life skills,' in other words to clarify the "muddy waters," we conducted a review to become acquainted with the organizations and scholars that are doing work related to life skills education. The process used for this analysis included the following core elements.

First, we engaged in a search and analysis of actors and stakeholders working in the field of international development education that are engaged in life skills education. This involved:

- Systematic online searches using key words (life skills, non-cognitive skills, skills, adolescent girls) to identify key stakeholders and initiatives in the field at global, regional, and national levels;

- A detailed desk review of key global initiatives using websites and other available resources, particularly policy or project documents;

- Interviews with key actors in life skills education including researchers, donors, and multi-lateral agencies who convened for a workshop on Life Skills education held at UC Berkeley in May, 2018. Additionally, we have attended panel sessions at international conferences to gain insights into work that has not yet been published or posted on agency websites.

- A comprehensive review of published studies to examine the evidence base regarding the impact of life skills education (Murphy-Graham \& Cohen, 2019, included in Table 2.4).

This analysis of actors and stakeholders, as well as the empirical literature, allowed us to identify emerging categories that we subsequently labelled "discourse communities."

\section{Findings: What Are Skills and Why Do They Matter for Education?}

Our review and analysis suggest three converging bodies of research and practice that have resulted in the rise of life skills education programming. The first includes work among scholars and practitioners in the field of prevention science, which broadly sees life skills as important for preventing drug and alcohol use, as well as preventing sexually transmitted diseases (particularly HIV), early pregnancy, and other risky behaviors. The second is the discourse community that has been influenced by the work of Nobel-prize winning economist James Heckman, who with co-authors, has argued that the predictive power of skills rivals that of cognitive skills, and so interventions should focus on fostering such skills. Life skills are instrumental to 'promoting lifetime success' particularly in the labor market (Kautz et al., 2014). Heckman and co-authors have drawn upon the Big Five Personality 
theory in the field of Psychology, a framework for understanding personality traits with five factors: openness, contentiousness, extraversion, agreeableness, and neuroticism. Finally, a third community focuses on life skills because they see getting youth into school as an insufficient step in transforming lives and communities. Rather, they focus on broadening what is taught in school to ensure education can be useful for life broadly (not just for health or work). Table 2.1 below summarizes these three discourse communities, and each are described in greater detail in the sections that follow.

Table 2.1 Summary of three discourse communities that emphasize life skills

\begin{tabular}{|c|c|c|c|}
\hline $\begin{array}{l}\text { Discourse } \\
\text { community \& } \\
\text { related } \\
\text { disciplines }\end{array}$ & Goals & $\begin{array}{l}\text { Life skills emphasized } \\
\text { as... }\end{array}$ & $\begin{array}{l}\text { Examples of } \\
\text { organizations/ } \\
\text { interventions aligned } \\
\text { with this discourse } \\
\text { community }\end{array}$ \\
\hline $\begin{array}{l}\text { Prevention and } \\
\text { protection } \\
\text { (Public Health/ } \\
\text { Social Work) }\end{array}$ & $\begin{array}{l}\text { Life skills for healthy } \\
\text { choices } \\
\text { Protection from risky } \\
\text { behavior (e.g. drug use, } \\
\text { unprotected sex, gang } \\
\text { involvement) }\end{array}$ & $\begin{array}{l}\text { Decision-making } \\
\text { Communication } \\
\text { Resist peer pressure } \\
\text { Self-knowledge and care }\end{array}$ & $\begin{array}{l}\text { Life Skills Training } \\
\text { program } \\
10 \text { programs reviewed } \\
\text { in 'Sexuality } \\
\text { Education: a ten } \\
\text { country review of } \\
\text { school curricula in East } \\
\text { and Southern Africa' } \\
\text { (Population Council, } \\
\text { 2012) }\end{array}$ \\
\hline $\begin{array}{l}\text { Labor market } \\
\text { outcomes } \\
\text { (Economics) }\end{array}$ & $\begin{array}{l}\text { Life skills for labor } \\
\text { market outcomes } \\
\text { including employment, } \\
\text { productivity, job quality, } \\
\text { entrepreneurship, } \\
\text { earnings. }\end{array}$ & $\begin{array}{l}\text { 'Big five' personality } \\
\text { domains } \\
\text { (conscientiousness, } \\
\text { openness, extraversion, } \\
\text { agreeableness, } \\
\text { neuroticism/emotional } \\
\text { stability) } \\
\text { Teamwork } \\
\text { Communication } \\
\text { Problem-solving }\end{array}$ & $\begin{array}{l}\text { A Ganar Program } \\
\text { (Sports-based life skills } \\
\text { training program for } \\
\text { youth in } 21 \text { countries) } \\
\text { Juventud y Empleo } \\
\text { (Youth and } \\
\text { Employment program } \\
\text { in the Dominican } \\
\text { Republic) } \\
\text { Programs reviewed in } \\
\text { 'Skills Training } \\
\text { Programs' (J-PAL, } \\
\text { 2017) }\end{array}$ \\
\hline $\begin{array}{l}\text { Quality } \\
\text { education } \\
\text { (Education) }\end{array}$ & $\begin{array}{l}\text { Life skills for range of } \\
\text { well-being outcomes \& } \\
\text { meeting day to day } \\
\text { challenges and making } \\
\text { informed decisions }\end{array}$ & $\begin{array}{l}\text { Leadership } \\
\text { Communication } \\
\text { Critical thinking } \\
\text { Social and emotional } \\
\text { competencies } \\
\text { Twenty-first century skills }\end{array}$ & $\begin{array}{l}\text { CAMFED (Campaign } \\
\text { for Female Education } \\
\text { for girls in five African } \\
\text { countries) } \\
\text { Room to Read } \\
\text { Brookings Institution } \\
\text { (see Kwauk \& Braga, } \\
\text { 2017; Winthrop \& } \\
\text { McGivney, 2016) }\end{array}$ \\
\hline
\end{tabular}


Table 2.2 Core ideas and areas of overlap in the three discourse communities

\begin{tabular}{|c|c|c|c|}
\hline $\begin{array}{l}\text { Areas of } \\
\text { overlap: }\end{array}$ & $\begin{array}{l}\text { Prevention and } \\
\text { protection }\end{array}$ & Labor market outcomes & Quality education \\
\hline $\begin{array}{l}\text { Mastery of } \\
\text { certain tasks/ } \\
\text { knowledge/ } \\
\text { information }\end{array}$ & $\begin{array}{l}\text { HIV/STD prevention } \\
\text { knowledge and proper } \\
\text { use of birth control } \\
\text { methods } \\
\text { Drug/alcohol harm } \\
\text { reduction and } \\
\text { knowledge } \\
\text { Legal information } \\
\text { (e.g., legal drinking } \\
\text { age) }\end{array}$ & $\begin{array}{l}\text { Specific information or } \\
\text { performance tasks related to } \\
\text { jobs or entrepreneurship (e.g., } \\
\text { carpentry, computer } \\
\text { technician, social outreach, } \\
\text { sales and marketing) }\end{array}$ & $\begin{array}{l}\text { Range of academic } \\
\text { subjects } \\
\text { Identification of life } \\
\text { goals } \\
\text { Ability to identify } \\
\text { power structures in } \\
\text { society } \\
\text { Familiarity with the } \\
\text { concepts of gender } \\
\text { norms, equality vs. } \\
\text { equity }\end{array}$ \\
\hline $\begin{array}{l}\text { Social and } \\
\text { emotional } \\
\text { competencies }\end{array}$ & $\begin{array}{l}\text { Self-control } \\
\text { Communication } \\
\text { Assertiveness/refusal } \\
\text { Empathy } \\
\text { Negotiation } \\
\text { Self-Confidence/ } \\
\text { esteem }\end{array}$ & $\begin{array}{l}\text { Regulating emotions } \\
\text { Communication } \\
\text { Teamwork } \\
\text { Perseverance/grit } \\
\text { Personal awareness \& } \\
\text { management }\end{array}$ & $\begin{array}{l}\text { Negotiation } \\
\text { Self-confidence } \\
\text { Relationships } \\
\text { (mentors) } \\
\text { Perseverance } \\
\text { Empathy } \\
\text { Self-reliance } \\
\text { Communication } \\
\text { (facilitation, } \\
\text { presentation skills, } \\
\text { 'voice') }\end{array}$ \\
\hline $\begin{array}{l}\text { Critical thinking/ } \\
\text { ways of thinking }\end{array}$ & $\begin{array}{l}\text { Critical examination } \\
\text { of power structures in } \\
\text { society related to } \\
\text { gender and social class }\end{array}$ & $\begin{array}{l}\text { Problem solving } \\
\text { Decision making } \\
\text { Critical creative thinking }\end{array}$ & $\begin{array}{l}\text { Critical thinking and } \\
\text { problem solving } \\
\text { Need to analyze } \\
\text { context and power } \\
\text { Goal-orientation } \\
\text { Decision making }\end{array}$ \\
\hline
\end{tabular}

The three discourse communities have different areas of emphasis for their work in life skills, though there is some overlap. While these three discourse communities conceptualize and have different outcome targets, there is also convergence around the idea that adolescents need to: (1) master certain tasks, knowledge and/or information, (2) develop a group of social and emotional competencies that will lead to valuable behaviors, and; (3) have ways of thinking that we consider to fall within the category of critical thinking. Table 2.2 summarizes these areas of convergence, and each of these discourse communities is described in greater detail in the sections that follow.

At a general level, this common ground across the three discourse communities (mastery of certain tasks/knowledge/information; group of social and emotional competencies; critical thinking/ways of thinking), might help to create a better starting place for identifying common programmatic pedagogies, goals, and assessments. Furthermore, a brief understanding of the historical development and evolution of these discourse communities helps clarify why there is so much 
variability in the outcomes programs currently emphasize. Understanding this history is a critical step towards improving future work in life skills education.

\section{Life Skills for Prevention}

In 'prevention' education programs (drugs, tobacco, alcohol, violence, teenage sex, pregnancy, other risky behavior), life skills have a long history of prominent placement. One of the leading life skills programs in this field, called Life Skills Training (LST), began in the 1970s under the leadership of Dr. Gilbert Botvin. Botvin was trained as a clinical and developmental psychologist at Columbia University, and his first job was with the American Health Foundation, which was at the cutting edge of the field that eventually became known as preventative medicine. He became interested in risk reduction and behavioral interventions that might modify or enrich the development or risk factors. Convinced that major social and psychological factors promote the initiation of substance use and other risky behaviors, he developed a program he eventually called 'life skills' that had to do with promoting overall competency and more effective adolescent development, a more comprehensive approach targeting individual risk factors. LST is perhaps the best-known drug prevention program, and has been used with youth in all 50 states and all the territories of the USA, and it has been used in 39 countries across all six habited continents. LST has also demonstrated beneficial outcomes in over 35 rigorous evaluation studies (see Botvin LifeSkills Training, n.d.).

The LST program consists of three major components that "cover the critical domains found to promote drug use... Research has shown that students who develop skills in these three domains are far less likely to engage in a wide range of high-risk behaviors" (See: https://www.lifeskillstraining.com/lst-overview/). The three components are drug resistance skills, personal self-management skills, and general social skills. Given the goals of this program, the empirical work on LST emphasizes outcomes of drinking, cigarette, and drug use, rather than measuring life skills as outcome variables. Different variations of the curriculum have been tested (the standard curriculum lasts 15 weeks and is implemented in schools).

Prevention programs that targeted the HIV/AIDS epidemic followed this model, often linking life skills training with content knowledge about how to prevent disease transmission (similar to linking content knowledge about tobacco, alcohol, and drugs in LST). As Boler and Aggleton (2005) explain, in the early 1990s, "when it became apparent that many young people (and adults) were not going to change their sexual behavior merely because they were told that they should, the international development community - particularly UNICEF — rallied around the idea of teaching life skills as part of HIV/AIDS education" (p. 1). The idea had its roots in the same body of scholarship from North America and European psychology, but not necessarily referencing prevention. Rather, it focused on the qualities of successful leadership. Over time, and in an attempt to make the skills more appealing to governments and communities, the term 'life skills' began to encompass an 
ever-increasing level of generic skills, including communicating, listening carefully, empathy-building, and income-generation. In 2005, Boler and Aggleton argued that claims regarding the role of these life skills in preventing HIV were made largely with no evidence (particularly with regards to sexual behavior).

A review of the effects and effectiveness of Life Skills Education for HIV prevention in young people (Yankah \& Aggleton, 2008) found that most interventions to prevent HIV included a life skills component, and that programs worked best to positively influence knowledge, attitudes, intentions, skills, and abilities. However, life skills programs rarely produced consistent effects on sexual behavior or biological outcomes (the contraction of STDs). (This finding appears to remain true for more recent studies, such as Dunbar et al., 2010.) Similar to the LST studies, these evaluations focus on behavioral outcomes and so we can learn little about the ways in which the programs impact life skills (as outcomes in and of themselves) and if changes in life skills are associated with any beneficial long-term outcomes (such as egalitarian intimate relationships) over time.

Despite a lack of documented impact of life skills training programs to prevent HIV, a "regional curriculum scan" conducted in 2011 (commissioned by UNESCO and UNFPA and authored by the Population Council, 2012) found that some form of "skills" was included in the HIV/prevention curricula of 10 African countries. However, the content was often deemed 'weak', particularly in terms of fostering critical thinking skills and advocacy skills. A subsequent review (Haberland, 2015) of rigorous evaluations of sexuality and HIV education programs found that most of the programs that met the review criteria had "skills" (not precisely defined) as a component of their curricula. However, what the review found was that the programs that addressed gender and power were five times more likely to be effective than those that did not. This points to the idea that the skill of "critical thinking about gender and power' might be among the most important life skills for the prevention of HIV and changing sexual behavior.

We identified 43 empirical studies focusing on life skills for youth in developing country contexts published after 2005 - of these, we classified 35 in the prevention discourse community. As detailed in Table 2.4, many of these studies are from India $(\mathrm{N}=21)$. Other countries include Iran, Nigeria, Kenya, South Africa, Indonesia, Mexico, Pakistan, Thailand, Zambia and Zimbabwe. Many outcome variables are studied: health risk behavior; condom use; HIV knowledge; smoking; and a range of psychosocial outcomes ("positive emotions," resisting peer pressure, selfknowledge). The rigor of these studies is quite variable, and the totality of evidence is not compelling due in part to the time frame (with research conducted immediately upon program completion) and the lack of specificity regarding measures used and research procedures (see Table 2.4). 


\section{Skills for Labor Market Productivity}

In a recently published paper "Does Education Strengthen the Life Skills of Adolescents?" the "elevator pitch" is that "life skills, sometimes referred to as noncognitive skills or personality traits (e.g., conscientiousness or locus of control - the belief to influence events and their outcomes), affect labor market productivity" (Schurer, 2017, p. 1). This paper is consistent with the discourse community of economists, who, drawing upon the work of personality psychologists, explore the relationship between "skills" and later life outcomes (including health and labor market). They also seek to understand which traits are malleable through educational interventions.

The work of James Heckman, Nobel Laureate in economics and Professor at the University of Chicago, and his co-authors on skills has allowed the concept to gain heft but unfortunately has not helped provide conceptual clarity. This is in part because Heckman's own use of the term has evolved over time. In earlier publications, Heckman referred to "non-cognitive" skills (Heckman et al., 2006, pp. 411-82). In a much-cited paper published by the National Bureau of Economics Research, Heckman and his co-author Tim Kautz use the term "character skills" (2013). In an OECD report that draws upon this 2013 paper, the authors revert to the term "non-cognitive" (Kautz et al., 2014). In his 2016 paper published in the journal Human Development and Capabilities, Heckman and his co-author Chase Corbin use the term "skills" without a modifier (Heckman \& Corbin, 2016). While the specific wording of his argument has evolved, the crux of Heckman's message is that the notion of "skill" is a useful one because "skill suggests that these attributes can be learned... all attributes can be shaped" (Heckman \& Kautz, 2013, p. 10; emphasis added). Heckman has also been consistent in his message regarding the inadequacy of outdated modes of measuring what might predict long-term life outcomes, namely IQ and other achievement tests. ${ }^{3}$ Interventions must also target "character skills" valued in the labor market, in school, and other domains (Heckman \& Kautz, 2013).

Given the widespread popularity and diffusion of these ideas, a closer examination of how Heckman and his co-authors conceptualize "skills" is warranted. Table 2.3 below lists ways in which Heckman and co-authors have explained and written about skills.

Heckman and his co-authors use the term "skill" as the broadest possible category - essentially to capture anything important for personal and social well-being (even referring to "health" as a skill). In Heckman and Kautz (2013), greater attention is given to the field of psychology and its "relatively well-accepted" taxonomy of descriptors or temperament attributes of personality. These are the "Big Five" domains, including conscientiousness, openness to new experience, extraversion, agreeableness, and neuroticism/emotional stability. ${ }^{4}$ From these traits, Heckman and Kautz (drawing upon a table adapted from psychologists John and Srivastava) list a number of facets, related skills, and "analogous childhood temperament skills" (2013, p. 12). However, they are careful not to use the label "traits" as they believe 
Table 2.3 Heckman and co-authors' conceptualizations of skills

\begin{tabular}{l|l}
\hline & Skills are: \\
\hline Keckman and & $\begin{array}{l}\text { Character skills are universally valued across all cultures and societies (p. 4) } \\
\text { Skills enable people. They are capacities to function. Greater levels of skill } \\
\text { foster social inclusion and create social well-being. Skills give agency to people } \\
\text { to shape their lives in the present and to create future skills (p. 5). } \\
\text { Character skills include perseverance ("grit"), self-control, trust, attentiveness, } \\
\text { self-esteem and self-efficacy, resilience to adversity, openness to new } \\
\text { experience, empathy, humility, tolerance of diverse opinions and the ability to } \\
\text { engage productively in society (p. 6). }\end{array}$ \\
\hline Heckman and & $\begin{array}{l}\text { Skills - broadly defined - are major sources of well-being and flourishing in } \\
\text { society (p. 344). } \\
\text { The current literature on the economics of human development recognizes the } \\
\text { multiplicity of skills that characterize human diversity and contribute to creating } \\
\text { flourishing lives (p. 343). } \\
\text { Personality skills - that is, "soft skills" such as trust, altruism, reciprocity, } \\
\text { perseverance, attention, motivation, self-confidence, and personal health - are } \\
\text { also important (p. 345). } \\
\text { Health and mental health are essential skills (p. 345). }\end{array}$ \\
\hline
\end{tabular}

that this term signifies a sense of "permanence and possibly also of heritability" (Heckman \& Kautz, 2013, p. 10).

Heckman and Kautz explain that they use the term skills rather than traits because "skills suggests that these attributes can be learned, both cognitive and character skills can change and be changed over the course of the lifecycle" (2013, p. 10; emphasis added). While research in psychology does indicate that personality traits change throughout the lifecycle ${ }^{5}$ the claim Heckman and Kautz make regarding how traits can "be changed" (through interventions) is debatable. How and why personality traits change and the degree to which they can change through interventions over time is an active research area in the field of psychology.

Heckman's work is cited by a number of donor agencies that work in the life skills area - including the World Bank, who published the brief "Life Skills: What Are They, Why do They Matter, and How Are They Taught?' in 2013. In this brief, they draw heavily from Heckman's work as well as other economists who write from a human capital perspective. In short, in this perspective, life skills matter because they have positive implications for health, education, and labor market outcomes.

The empirical evidence base regarding the effectiveness of labor market training programs that focus on life skills suggests mixed results, with some studies showing that training has little effect and others finding a positive long run effect (J-PAL, 2017). Some of this research has focused on the pedagogy and educational strategies used to deliver training programs, and some encouraging results from randomized evaluations of programs that combine an emphasis on "cognitive" and "noncognitive" skills training improve educational trajectories and graduation rates, and they have positive effects on labor market outcomes (J-PAL, 2017). One example of this is the randomized evaluation of the A Ganar program, a sports-based job training program that emphasizes technical skills as well as "life and employability" 
skills featured in Murphy-Graham (Chap. 7, this volume). While the program did not have any significant effect on the employment rate, or number of jobs or hours worked by participating youth, there was a positive impact on job "quality" as measured by wages, benefits, and job satisfaction (Duthie et al., 2018).

A recent review of interventions to strengthen the life skills of adolescents found that there is a small evidence base regarding labor market outcomes, and so general conclusions are not possible. Measurement of life skills has also proven very difficult, which raises concerns regarding the validity of the findings (Schurer, 2017). Despite these findings, there is some consensus that adolescence offers a window of opportunity to teach life skills through training programs. However, compared with early-childhood programs, the evidence on adolescent programs is less abundant (Heckman \& Kautz, 2013). Furthermore, "there remains a feeling that [skills] training must be a key component of labor market integration given the large gap between the very low skill level of young people and the needs of firms, especially in developing countries" (J-PAL, 2017, p. 1). Table 2.4 includes two additional studies that focus on labor market outcomes, both of which had mixed results.

\section{Life Skills for Quality Education}

"A poor quality education is almost like no education. Great progress has been achieved in enrolling children in school around the world. But it is not enough to get children in school. We also need to ensure they learn to read, count and acquire the necessary life skills." This message, which appears on the front page of the Global Partnership for Education website, ${ }^{2}$ exemplifies how life skills are a key component of the "bottom line" message about educational quality that currently circulates among key policy actors in the field of international development education. In addition to basic literacy and numeracy, life skills are a key component of education quality. In short, there is consensus that improving the quality of education is a key international goal, but there are many different notions of what constitutes quality education. Among these different conceptualizations of quality education, there is consensus that students should develop life skills (Barrett et al., 2006; DeJaeghere et al., 2016; Nikel \& Lowe, 2010; Tikly \& Barrett, 2011; UNICEF, 2010; World Bank, 2018).

This third discourse community, which we call "quality education," has emphasized life skills education in part due to growing recognition that children and adolescents in developing countries do not always benefit from extended years of schooling in terms of what they are learning. Referred to as the "learning crisis", the critique is that the curriculum is highly academic and that it is disconnected from what adolescents need to learn to do everyday tasks and engage in community life. Furthermore, what the curriculum does emphasize, namely basic literacy and

\footnotetext{
${ }^{2}$ See https://www.globalpartnership.org/education
} 


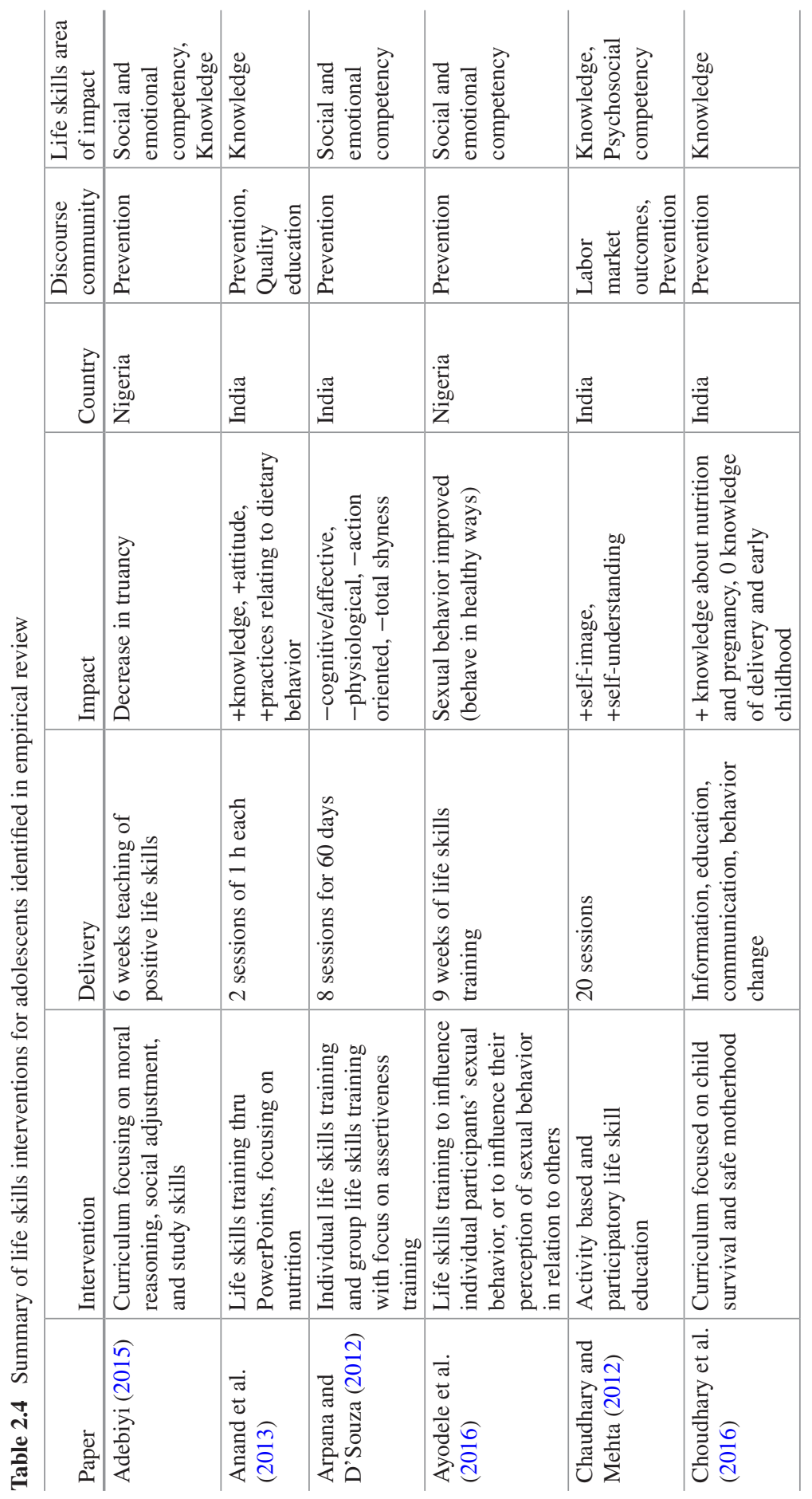




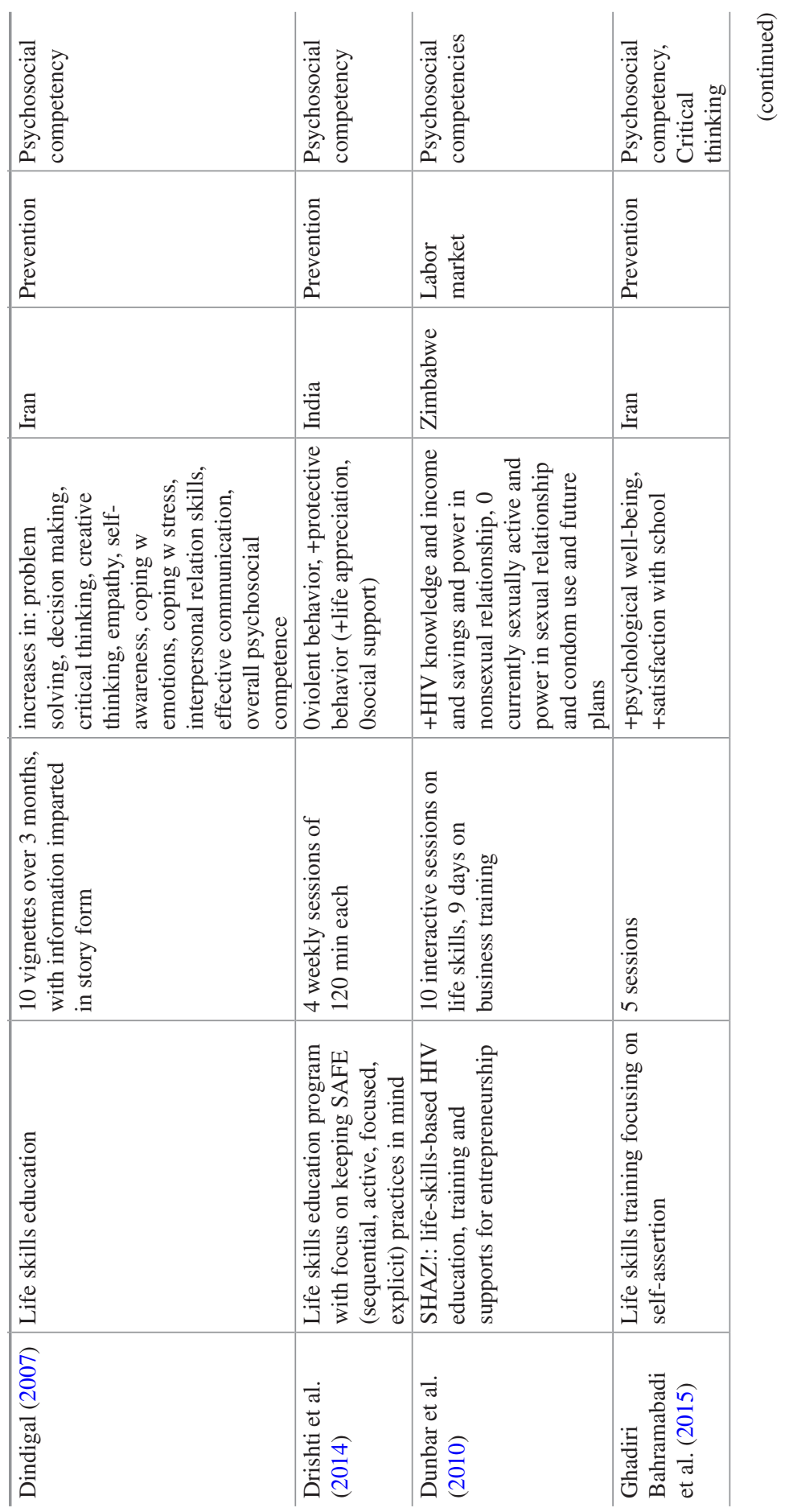




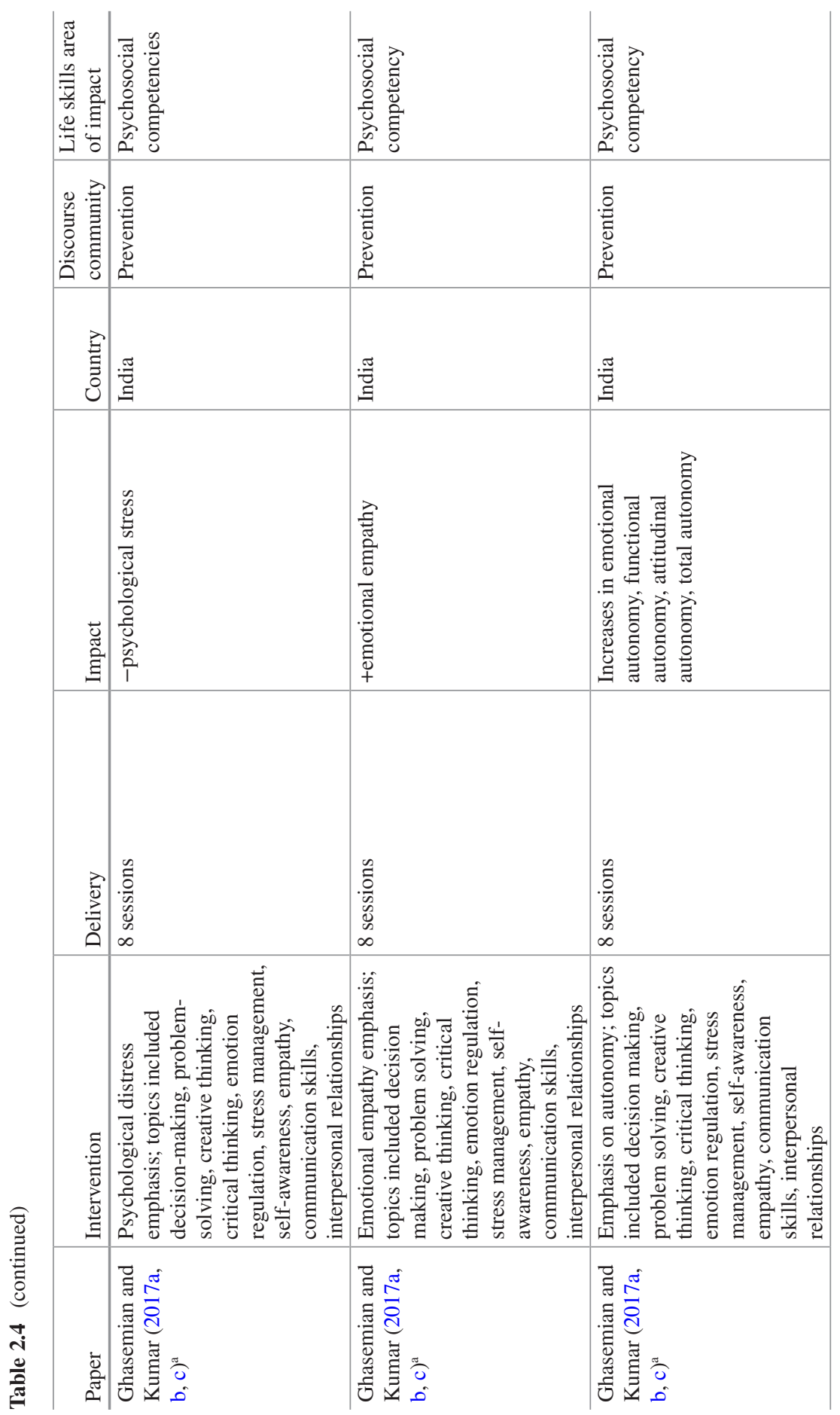




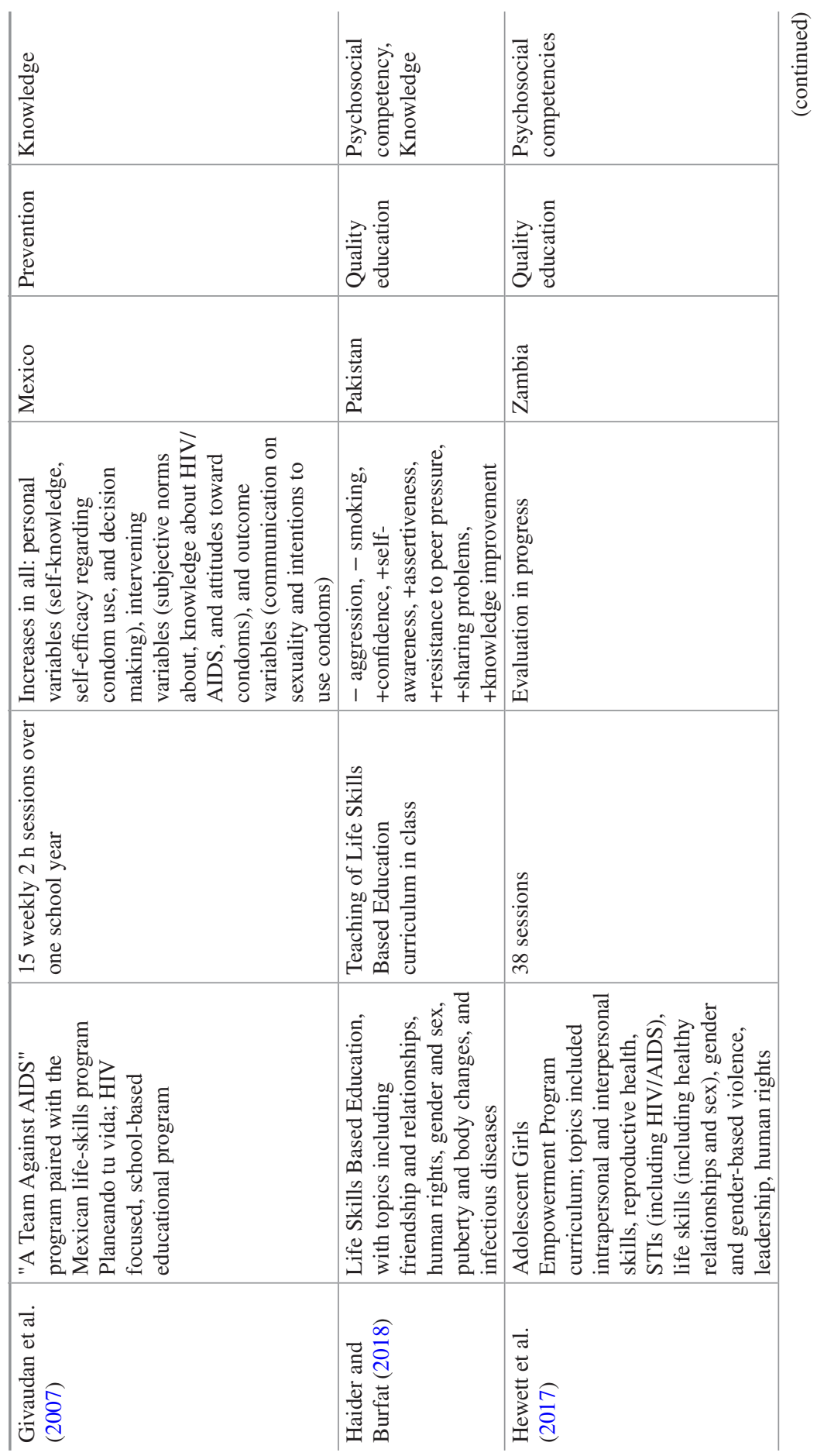




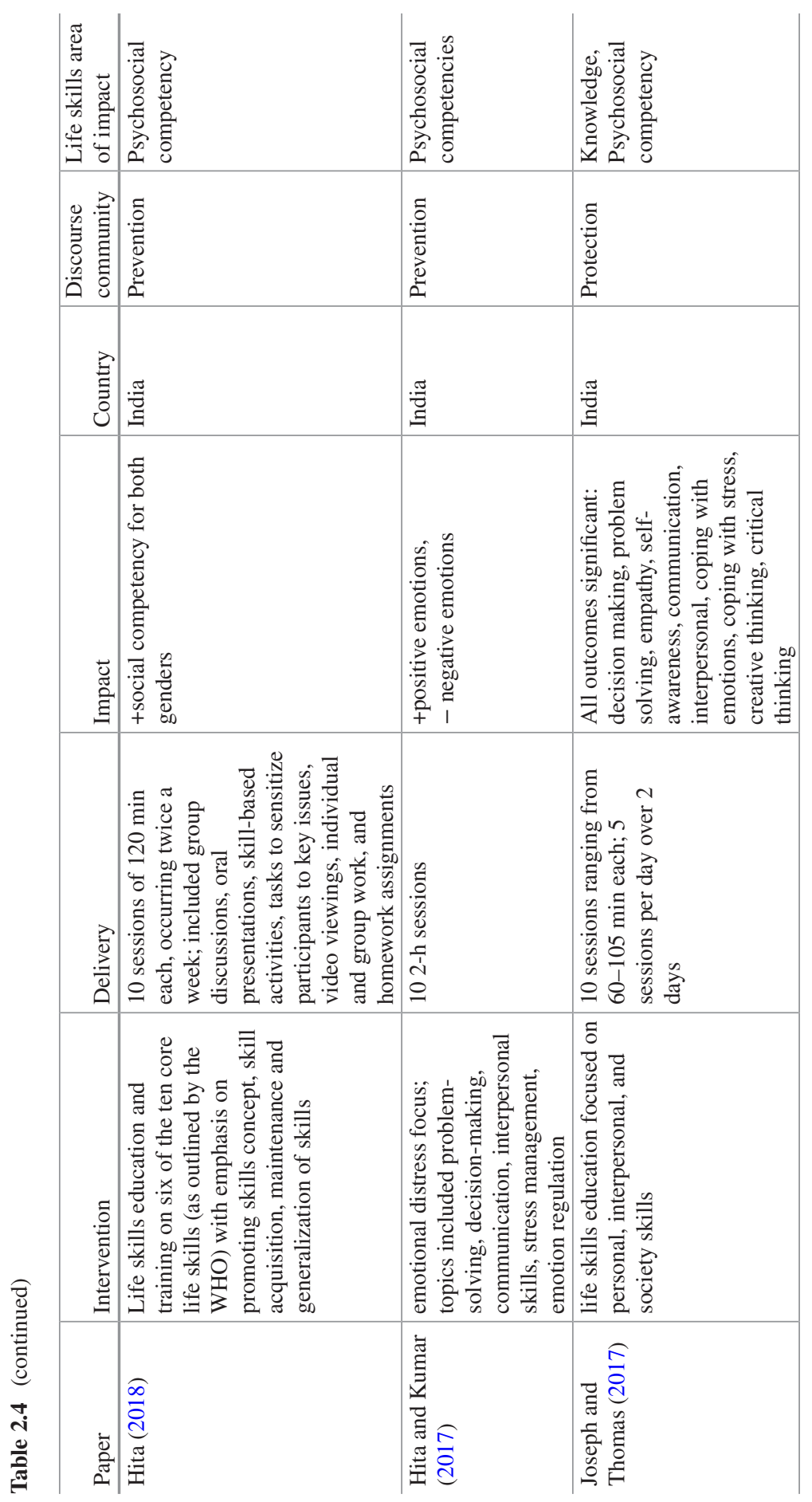




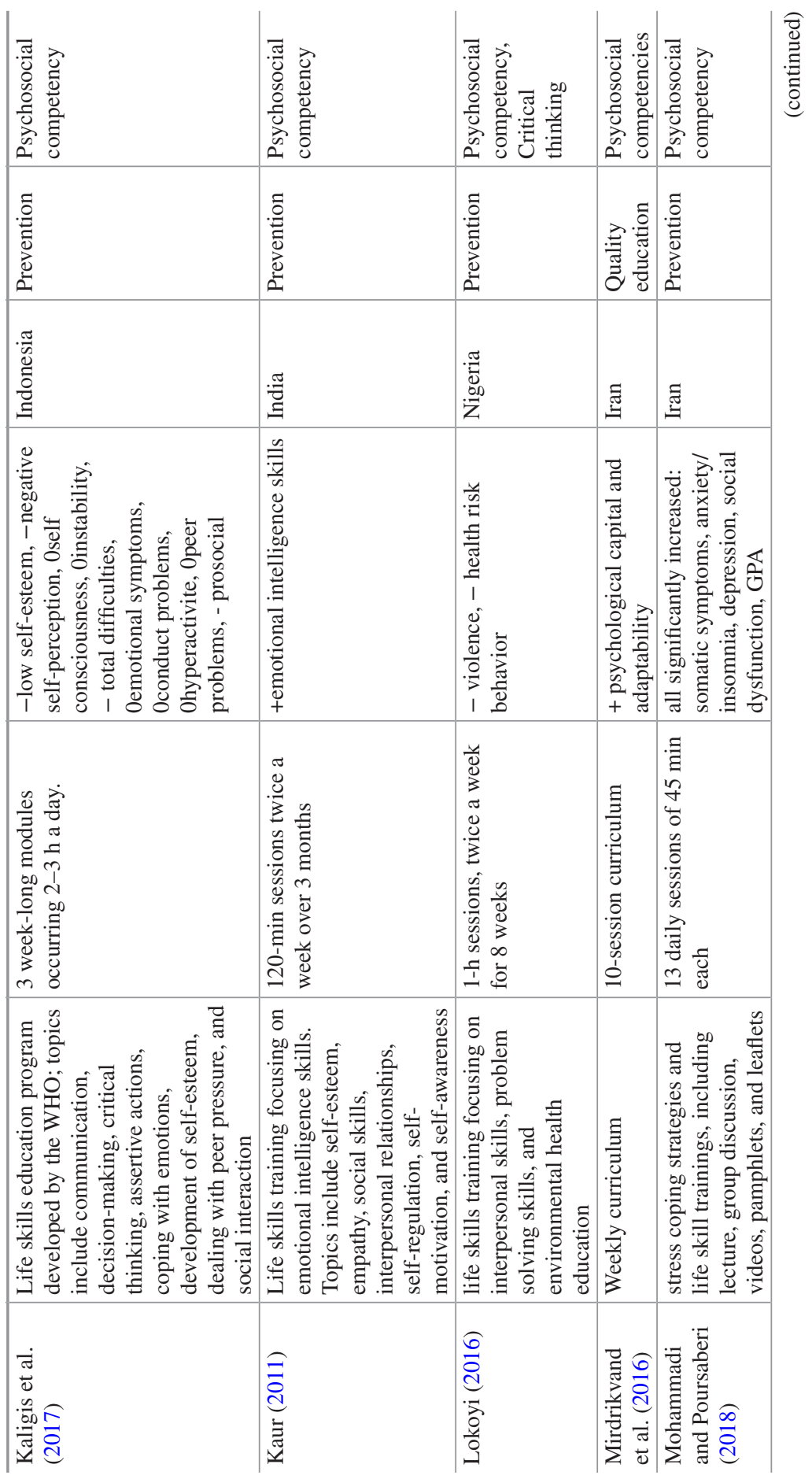




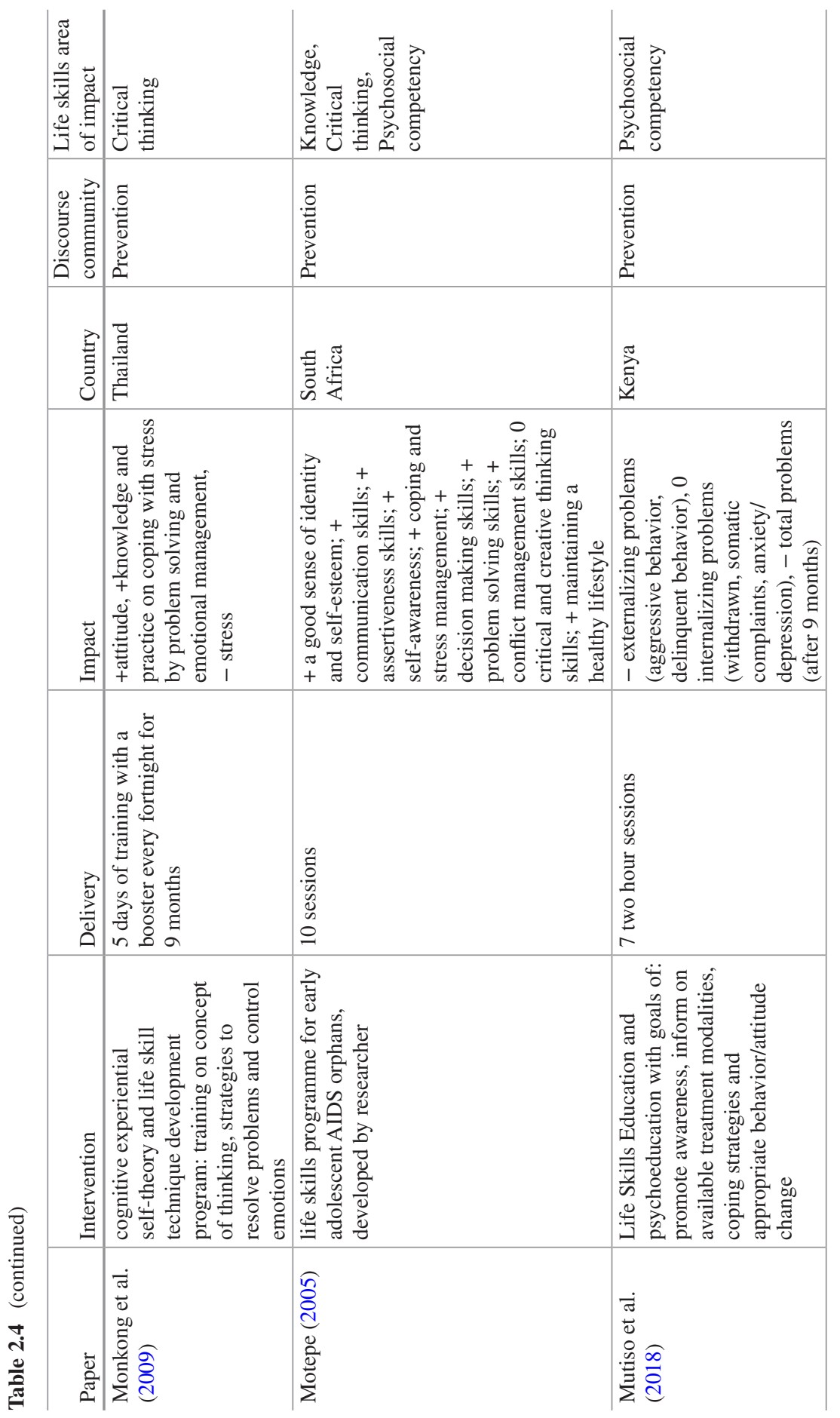




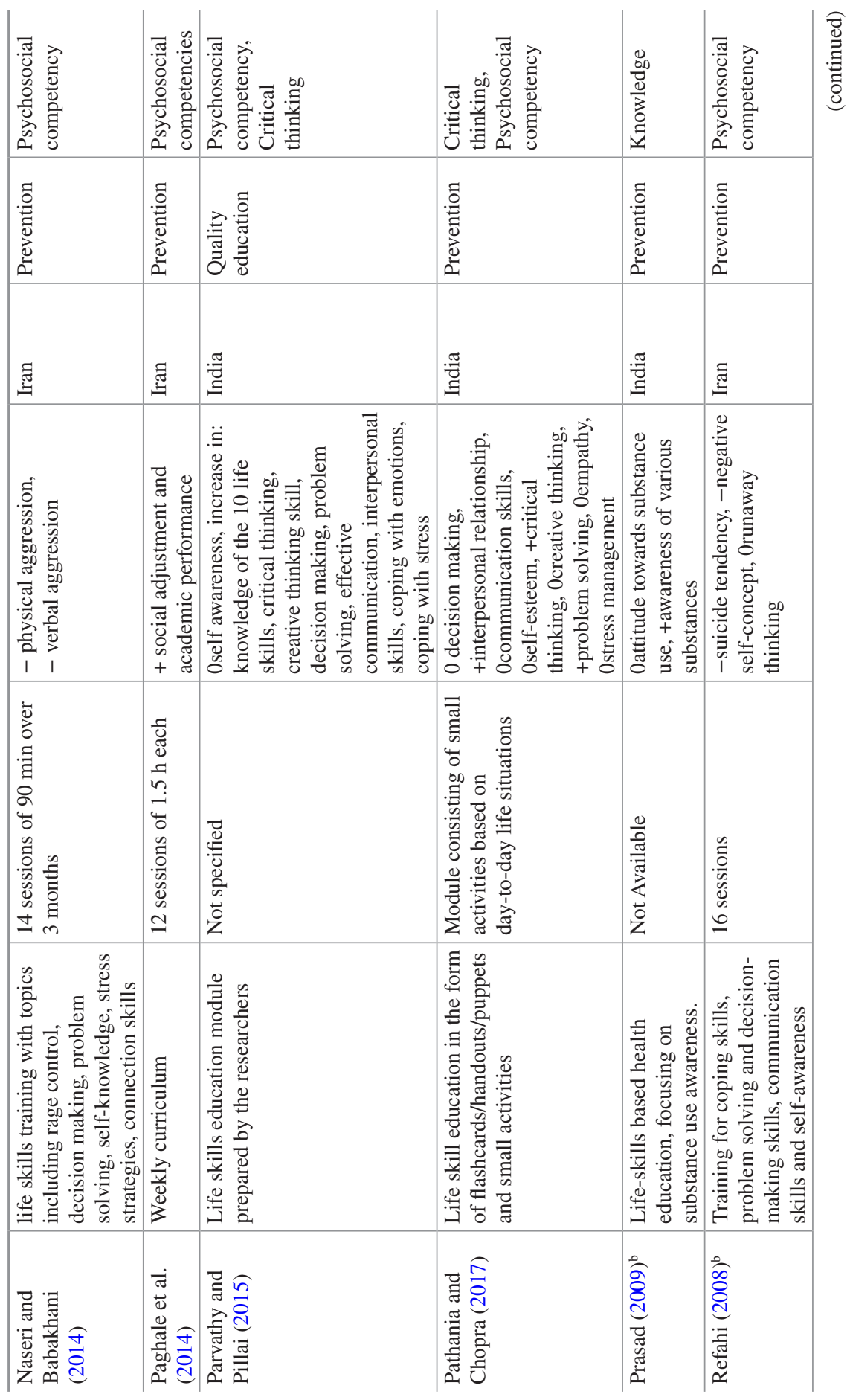




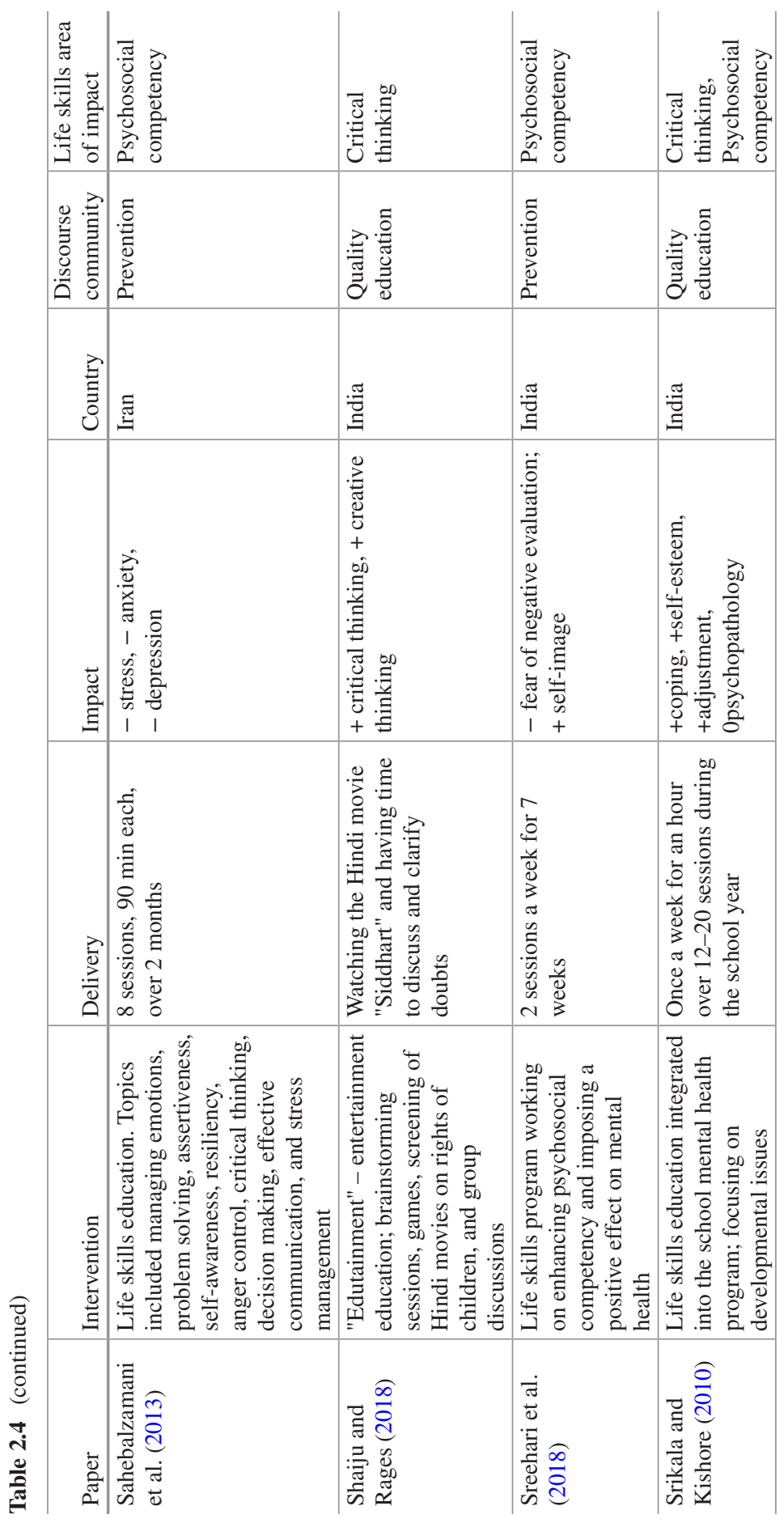




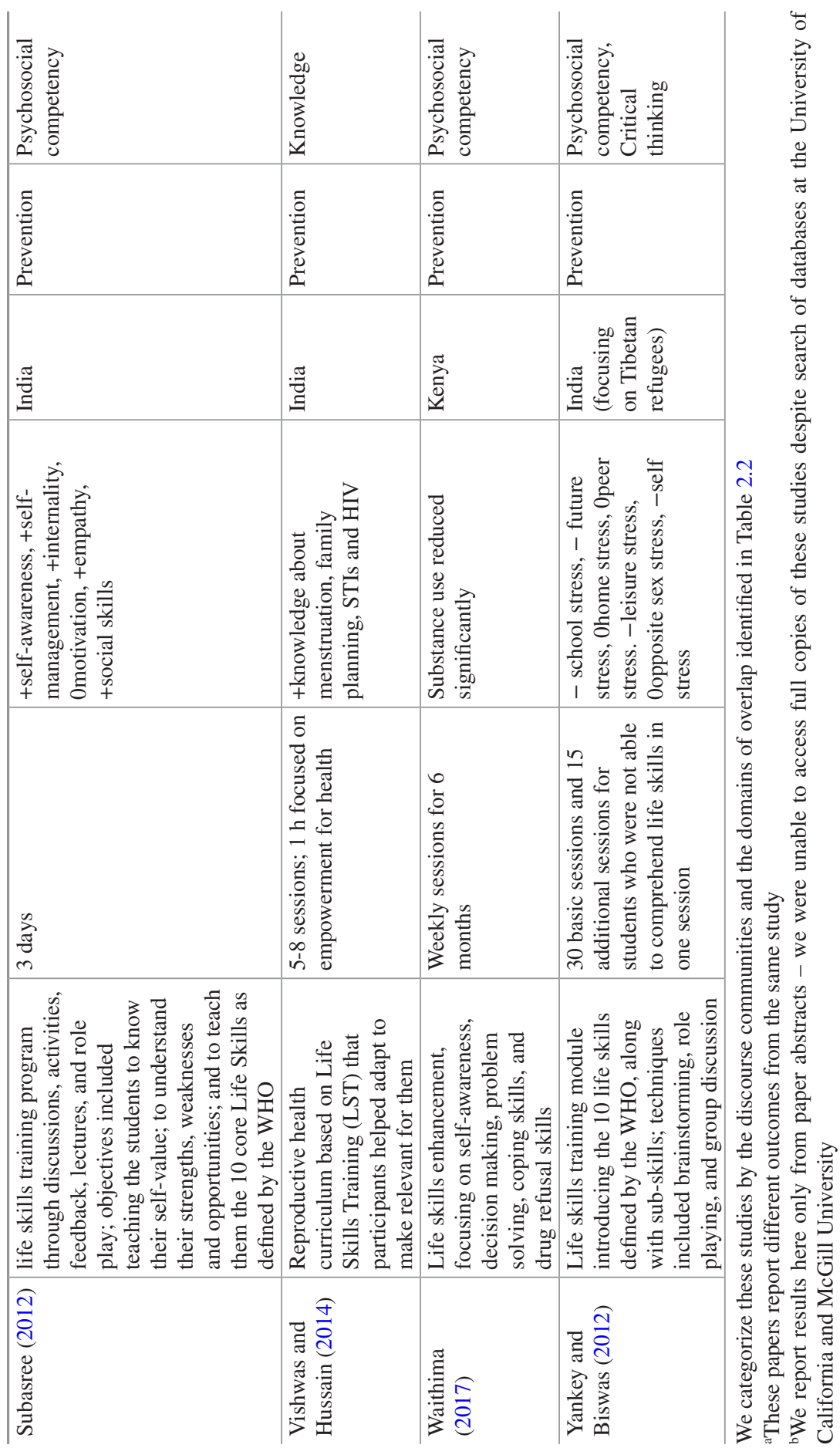


numeracy, also has abysmal outcomes. This recognition and its perceived importance spurred the publication of the World Bank World Development Report "Learning to Realize Education's Promise", which begins with an overview of the dimensions of the learning crisis (World Bank, 2018).

Policy statements and documents from the World Bank, blogs by Washington think tanks such as the Brookings Institution, and commissioned research programs such as DFID's EdQual or the Raising Learning Outcomes in Education Systems (RLO) attempt to grapple with how to improve teaching and learning in formal schools. Against this backdrop, international education actors including philanthropic foundations, bilateral and multilateral donors, and local and international non-governmental organizations have launched what is likely to be thousands of non-formal education programs that focus on life skills (a review of programs in just three countries identified 103 programs for adolescent girls) (Dupuy et al., 2018). These programs are intended to fill the void that is left by poor quality schools by serving children and adolescents who are enrolled in school with afterschool or summer programs. Additionally, they serve children and adolescents who never attended or have dropped out of school (potentially, at least in part, due to low quality).

Life skills education for adolescent girls has particularly gained prominence in the last decade. Advocates for girls' education have increasingly come to realize that the "get them into school and all will be well" was a faulty assumption (Sahni, 2017, and also in her discussion of the Prerna school, this volume). For many years, scholars and international organizations such as CARE and Plan International focused not on "life skills" per se, but rather on girls' and women's empowerment through education. Getting girls into school, through expanded access that often involved scholarships and cash transfers was just the first step of the empowerment process. The hope was, and continues to be, that education can be a site to challenge the gender norms that have caused under-representation of girls in the system. However, empowering educational experiences for girls within the formal system are rare (see Murphy-Graham \& Lloyd, 2016 for a review of empowering education for adolescent girls).

Some organizations that emphasize life skills education for girls often simultaneously emphasize girls' empowerment. However, a discursive shift seems to have taken place whereby life skills has recently become the focal point for organizations working with girls. These include organizations such as Advancing Girls' Education, BRAC, CAMFED, CARE, Plan International, Room to Read, and Save the Children. It is possible that "life skills" is a more palatable term for interventions because they do not explicitly include the word "power" and may therefore seem less radical or politically motivated. Engaging the term "life skills" may allow these organizations to more effectively engage ministries of education, who may be familiar and supportive of life skills programming because it is already a part of their HIV/AIDS prevention or technical and vocational training curriculum (mentioned in our discussion of the first and second discourse communities). Likewise, using the term "life skills" for girls rather than empowerment may enable NGOs to better forge 
allegiances with stakeholders familiar with labor market training programs (such as the business community).

An earlier review of programs to empower adolescent girls identified four competencies for empowerment that appeared across interventions. These included developing critical ways of thinking and learning, personal competencies, social competencies, and productive competencies (Murphy-Graham \& Lloyd, 2016). These same categories are often included in conceptualizations of life skills for adolescent girls. In addition to our Table 2.1 above, Kwauk and Braga (2017) and Dupuy et al. (2018) list organizations and their life skills definitions - common are an emphasis on critical thinking (sometimes called cognitive skills), personal skills, and interpersonal skills (including community living). However, as Kwauk and Braga (2017) point out, at the level of life skills education programming for girls, practitioners have often limited their scope to quite specific outcomes, such as sexual and reproductive health, gender-based violence, or labor market outcomes (and our identification of these as distinct discourse communities clarifies why this is the case). As such, life skills programming and its focus on communication, negotiation, self-efficacy, and self-esteem focuses on imparting technical knowledge and does not enable girls to act differently in her everyday life in her home and community (Kwauk \& Braga, 2017):

\footnotetext{
A narrow focus on skills, together with conflating knowledge as skills, can lead to problems in program, curriculum, and policy design, implementation, and assessment. In particular: misaligned interventions and outcomes; misidentified target skills; overlooked building blocks and/or strategic knowledge; ineffective pedagogy or program delivery; problems with measurement; and overstated claims about an intervention or the importance of specific skills (p. 6).
}

Kwauk and Braga further point out that life skills programs focus on impacts including risk for substance abuse, reduced risky sexual behavior, and mindset change, there is too little attention to whether or not life skills education leads to "transformative change between the individual girl and her social, political, and economic environment. It also does not address whether or how such change for a girl might combine into broader collective action that transforms existing social norms, behaviors, and power relations that have systematically placed girls and women at a disadvantage" (Kwauk \& Braga, 2017, p. 7). They propose a reconceptualization of life skills as competencies that are a mix of interpersonal, intrapersonal, and cognitive skills. Coupled with knowledge, and attitudes, these constitute a set of competencies (life skills) that enable youth to function, thrive, and adapt in their everyday lives (Kwauk \& Braga, 2017, p. 5). Their proposal is to more explicitly link or to "translate" girls' life skills education to social change. This feature - linking life skills competencies to social change - is not commonly present in most work on life skills, particularly from the other two discourse communities. An explicit focus on social change - and the life skills needed to foster change processes - is a more recent feature of scholarship that is consistent with earlier work on education for youth empowerment (see DeJaeghere et al., 2016; Murphy-Graham, 2012).

In part due to the recency of work in this discourse community, there is quite a slim evidence base regarding the effectiveness of interventions that attempt to 
improve the quality of education for youth (see Table 2.4). We found that, overall, there is little evidence to date that interventions have positive effects on life skills conceptualized as a combination of interpersonal, intrapersonal and cognitive skills. An earlier review of life skills education programs found that, while there are a very small number of rigorous evaluations of life skills programs benefitting adolescents, they "generally positively influence psycho-social and attitudinal outcomes, health and relationships. They can help to prevent early marriage and they help to develop important economic and cognitive skills" (Dupuy et al., 2018).

A narrative systematic review of life skills education (Nasheeda et al., 2018) reviews twenty-five studies (that met their inclusion criteria) in both developed and developing countries. This review concludes that the totality of quantitative evidence for the studies reviewed delivers encouraging prospects for improving life skills education programs. At the same time, their conclusions also echo Kwauk and Braga's (2017) finding that studies tend to focus on "life skills components" as opposed to "understanding what knowledge, skills and attitudes adolescents require in order for positive behavior change to occur" (Nasheeda et al., 2018, p. 13). There are two additional impact evaluations of life skills programming in progress: The Adolescent Girls Empowerment Program (Hewett et al., 2017) evaluation includes a number of validated scales/measures of self-efficacy, gender-normative beliefs, financial literacy, knowledge of sexual and reproductive health, as well as other outcomes of interest (including behavioral and biological outcomes). In addition to this study, the findings from a randomized control trial of the girls' education and life skills program implemented by Room to Read in India includes a life skills assessment tool that includes self-reported scales and activity-based tasks. While these two studies are informed by a notion of life skills that is broader in nature consistent with the educationist discourse community studies -they will, unfortunately, still not be able to capture the extent to which life skills programming can foster "transformative change between girls and her social, political and economic environment” (Kwauk \& Braga, 2017, p. 7).

\section{Conclusion}

The aim of this chapter has been to gain a clearer understanding of how life skills education has been conceptualized, given its popularity in the field of education. We identified three distinct discourse communities that are concerned with life skills education. To recap, these are: (1) 'prevention and protection' which includes practitioners and scholars in public health and social work, (2) 'labor market outcomes' which draws from the work of economists, and (3) 'quality education' which draws on the work of educationists. We identify three areas of synergy among these distinct communities which include mastering specific tasks/information and knowledge; development of a set of social and emotional competencies; and fostering critical ways of thinking. 
The identification of these synergies should not be considered a new framework or conceptualization of life skills - it is really intended to provide a least common denominator of sorts across these discourse communities. Focusing only on what is common across these discourse communities may be overly reductive. At the same time, a common framework or shared way of thinking about life skills that is multidimensional will be necessary to advance research and practice in the field. The identification of these three distinct discourse communities explains why actors in the field focus on differential program goals. Highlighting the core life skills elements across the discourse communities - critical ways of thinking, development of social and emotional competencies, and mastery of certain tasks and information allows for a common set of broadly shared goals for life skills programming.

This chapter, explaining how three discourse communities conceptualize life skills, and the areas of overlap between them, can help provide conceptual clarity and will hopefully advance research and knowledge in developing, implementing, and evaluating high-quality interventions that are adapted to local contexts to best support youth to live life well.

Acknowledgments We would like to thank Lana Downs, Neha Zahid, and Fernanda Chacon for research assistance, Cynthia Lloyd for comments, and Echidna Giving for financial support.

\section{References}

Adebiyi, O. O. (2015). Effects of three positive life skills on in-school adolescents' delinquent behavior of truancy in public secondary schools in Ibadan Metropolis, Nigeria [Unpublished master's thesis]. University of Ibadan. http://ir.library.ui.edu.ng/handle/123456789/719

Anand, T., Ingle, G. K., Meena, G. S., Kishore, J., \& Yadav, S. (2013). Effect of life skills training on dietary behavior of school adolescents in Delhi: A nonrandomized interventional study. Asia Pacific Journal of Public Health, 27(2), 1616-1626. https://doi.org/10.1177/1010539513486922

Arpana, S., \& D'Souza, L. (2012). Effectiveness of individual and group life skills training on shyness among adolescents. Journal of Psychosocial Research, 7(2), 249-255. Retrieved from https://search.proquest.com/docview/1346900673?accountid=12339

Ayodele, K., Olanipekun, O., \& Akinlana, T. (2016). Fostering positive sexual attitude among Nigerian adolescents through life skills training. Babcock University Journal of Education, 1(1), 32-38. https://www.babcock.edu.ng/oer/journals/bujed_september_2015.pdf\#page=32

Barrett, A. M., Chawla-Duggan, R., Lowe, J., Nikel, J., \& Ukpo, E. (2006). The concept of quality in education: A review of the 'international' literature on the concept of quality in education (EdQual working paper no. 3). University of Bristol.

Boler, T., \& Aggleton, P. (2005). Life skills-based education for HIV prevention: A critical analysis (No. 3). Save the Children and ActionAid International.

Botvin LifeSkills Training. (n.d.). LST Overview. https://www.lifeskillstraining.com/lst-overview/

Chaudhary, S., \& Mehta, B. (2012). Life skill education for the economically backward adolescent boys and girls: An intervention programme. International Journal of Social Sciences \& Interdisciplinary Research, 1(5), 63-72.

Choudhary, A. K., Saxena, D. M., \& Kaushal, R. (2016). A study to assess empowerment of adolescent girls in terms of knowledge-based life skills education about child survival and safe motherhood practices. The Journal of Obstetrics and Gynecology of India, 66(6), 480-484. https://doi.org/10.1007/s13224-015-0733-6 
DeJaeghere, J., Pellowski Wiger, N., \& Wangsness Willemsen, L. (2016). Broadening educational outcomes: Social relations, skills development, and employability for youth. Comparative Education Review, 60(3), 457-479.

Dindigal, A. (2007). Impact of life skills education on psychosocial competence of adolescents [Unpublished master's thesis]. Karnatak University. http://hdl.handle.net/10603/96188

Drishti, S., Kishore, J., Sharma, N., \& Shukla, A. (2014). Pilot study for process evaluation of school-based life-skills education program for prevention of violence in adolescents. Indian Journal of Youth and Adolescent Health, 1(2), 12-26.

Dunbar, M. S., Maternowska, M. C., Kang, M.-S. J., Laver, S. M., Mudekunye-Mahaka, I., \& Padian, N. S. (2010). Findings from SHAZ!: A feasibility study of a microcredit and lifeskills HIV prevention intervention to reduce risk among adolescent female orphans in Zimbabwe. Journal of Prevention \& Intervention in the Community, 38(2), 147-161. https:// doi.org/10.1080/10852351003640849

Dupuy, K., \& Halvorsen, S. (2016). Life skills, girls, and non-formal contexts in developing countries: A global literature review [Unpublished draft manuscript]. Chr. Michelsen Institute.

Dupuy, K., Bezu, S., Knudsen, A., Halvorsen, S., Kwauk, C., Braga, A., \& Kim, H. (2018). Life skills in non-formal contexts for adolescent girls in developing countries (CMI report no. 5). CMI \& Brookings Institution.

Duthie, M., Pucilowski, M., Anzoategui, L., Agpoon, B., \& Murphy-Graham, E. (2018). A Ganar alliance impact evaluation synthesis report Guatemala and Honduras. Social Impact. Washington, D.C. Available online https://pdf.usaid.gov/pdf_docs/PA00T78T.pdf.

Ghadiri Bahramabadi, F., Michaeli Manee, F., \& Issazadegan, A. (2015). The effect of life skills training on psychological well-being and satisfaction among female adolescents. Journal of Research and Health, 5, 347-357. http://jrh.gmu.ac.ir/files/site1/pages/ghadir10694i.pdf

Ghasemian, A., \& Kumar, G. V. (2017a). Effect of life skills training on psychological distress among male and female adolescent students. Indian Journal of Health and Wellbeing, 8(4), 279-282.

Ghasemian, A., \& Kumar, G. V. (2017b). Enhancement of emotional empathy through life skills training among adolescents students-A comparative study. Journal of Psychosocial Research, 12(1), 177-185.

Ghasemian, A., \& Kumar, G. V. (2017c). Evaluate the effectiveness of life skills training on development of autonomy in adolescent students: A comparative study. Indian Journal of Positive Psychology, 8(1), 68-72.

Givaudan, M., Van de Vijver, F. J., Poortinga, Y. H., Leenen, I., \& Pick, S. (2007). Effects of a school-based life skills and HIV-prevention program for adolescents in Mexican high schools. Journal of Applied Social Psychology, 37, 1141-1162. https://onlinelibrary.wiley.com/doi/ abs/10.1111/j.1559-1816.2007.00206.x

Haberland, N. A. (2015). The case for addressing gender and power in sexuality and HIV education: A comprehensive review of evaluation studies. International Perspectives on Sexual and Reproductive Health, 41(1), 31. https://doi.org/10.1363/4103115

Haider, S. I., \& Burfat, F. M. (2018). Improving self-esteem, assertiveness and communication skills of adolescents through life skills based education. Journal of Social Sciences and Humanities, 26(2), 157-175.

Heckman, J. J., \& Corbin, C. O. (2016). Capabilities and skills (Working paper no. 22339). National Bureau of Economic Research. https://doi.org/10.3386/w22339

Heckman, J. J., \& Kautz, T. (2013). Fostering and measuring skills: Interventions that improve character and cognition (Working paper no. 19656). National Bureau of Economic Research.

Heckman, J. J., Stixrud, J., \& Urzua, S. (2006). The effects of cognitive and noncognitive abilities on labor market outcomes and social behavior. Journal of Labor Economics, 24(3), 411-482.

Hewett, P. C., Austrian, K., Soler-Hampejsek, E., Behrman, J. R., Bozzani, F., \& JacksonHachonda, N. A. (2017). Cluster randomized evaluation of Adolescent Girls Empowerment Programme (AGEP): Study protocol. BMC Public Health, 17(1). https://doi.org/10.1186/ s12889-017-4280-1 
Hita, C. R. (2018). Life skills for enhancing social competence during adolescence. International Journal of Basic and Applied Research, 8(6), 526-535. http://www.pragatipublication.com/ assets/uploads/doc/87b20-526-535.13314.pdf

Hita, C. R., \& Kumar, G. V. (2017). Effect of life skills training on emotional distress: A comparative study between adolescent boys and girls. The International Journal of Indian Psychology, 5(1), 145-155. https://doi.org/10.25215/0501.018

Joseph, D., \& Thomas, B. (2017). Life skills development training for adolescent girls at riskrescued Devadasi girls in Karnataka. Artha - Journal of Social Sciences, 16(1), 1. https://doi. org/10.12724/ajss.40.1

J-PAL. (2017). J-PAL skills for youth program review paper (Review Paper). Abdul Latif Jameel Poverty Action Lab.

Kaligis, F., Diatri, H., \& Dharmono, S. (2017). Life skills program for improving adolescent mental health in the aftermath Mount Merapi eruption, Yogyakarta-Indonesia. ASEAN Journal of Community Engagement, 1(1), 59-71.

Kaur, T. D. (2011). A study of impact of life skills intervention training on emotional intelligence of college adolescents. Indian Journal of Psychological Science, 2(2), 112-125. http://www. napsindia.org/wp-content/uploads/2017/05/112-125.pdf

Kautz, T., Heckman, J. J., Diris, R., ter Weel, B., \& Borghans, L. (2014). Fostering and measuring skills: Improving cognitive and non-cognitive skills to promote lifetime success (Working Paper No. 20749). National Bureau of Economic Research. https://doi.org/10.3386/w20749

Kwauk, C., \& Braga, A. (2017). Translating competencies to empowered action: A framework for linking girls' life skills education to social change. Center for Universal Education at Brookings.

Lokoyi, O. O. (2016). Effects of school-based life skills training on violence and health risk behaviours among in-school adolescents in delta state [Unpublished master's thesis]. University of Ibadan. http://ir.library.ui.edu.ng/handle/123456789/4044.

Mirdrikvand, F., Ghadampour, E., \& Kavarizadeh, M. (2016). The effect of life skills training on psychological capital and adaptability of adolescent girls with irresponsible parents. Quarterly Journal of Social Work, 5(3), 23-30.

Mohammadi, M., \& Poursaberi, R. (2018). The effects of stress-coping strategies and life skills trainings on the mental health and academic progress of adolescent cancer patients: A quasiexperimental study. Nursing and Midwifery Studies, 7(1), 12-17.

Monkong, L., Pongpanich, S., Viwatwongkasem, C., Chantavanich, S., Wongpiromsarn, Y., \& Katz, L. (2009). The effectiveness of program developed from cognitive-experiential self- theory and life skills technique on adolescent coping with stress. Nepal Medical College Journal, $11(4), 225-228$.

Motepe, M. M. (2005). A life skills programme for early adolescent aids orphans [Unpublished doctoral dissertation]. University of Pretoria. https://repository.up.ac.za/handle/2263/29211

Murphy-Graham, E. (2012). Opening minds, improving lives: Education and women's empowerment in Honduras. Vanderbilt University Press.

Murphy-Graham, E., \& Cohen, A. (2019, April 14-18). Life skills education for adolescents: A landscape analysis and empirical review [Conference paper]. Comparative and International Education Society Conference, San Francisco, CA.

Murphy-Graham, E., \& Lloyd, C. (2016). Empowering adolescent girls in developing countries: The potential role of education. Policy Futures in Education, 14(5), 556-577. https://doi. org $/ 10.1177 / 1478210315610257$

Mutiso, V., Tele, A., Musyimi, C., Gitonga, I., Musau, A., \& Ndetei, D. (2018). Effectiveness of life skills education and psychoeducation on emotional and behavioral problems among adolescents in institutional care in Kenya: A longitudinal study. Child and Adolescent Mental Health, 23, 351-358. https://doi.org/10.1111/camh.12232

Naseri, A., \& Babakhani, N. (2014). The effect of life skills training on physical and verbal aggression male delinquent adolescents marginalized in Karaj. Procedia - Social and Behavioral Sciences, 116, 4875-4879. https://doi.org/10.1016/j.sbspro.2014.01.1041 
Nasheeda, A., Abdullah, H. B., Krauss, S. E., \& Ahmed, N. B. (2018). A narrative systematic review of life skills education: Effectiveness, research gaps and priorities. International Journal of Adolescence and Youth, 24(3), 1-18. https://doi.org/10.1080/02673843.2018.1479278

Nikel, J., \& Lowe, J. (2010). Talking of fabric: A multi-dimensional model of quality in education. Compare: A Journal of Comparative and International Education, 40(5), 589-605. https://doi. org/10.1080/03057920902909477

Paghale, Z., Paghale, S., Jadidi Feighan, M., \& Nazary, M. (2014). The effect of life skills training on social adjustment and academic performance of adolescent female students. Knowledge \& Research in Applied Psychology, 15(4), 121-129.

Parvathy, V., \& Pillai, R. R. (2015). Impact of life skills education on adolescents in rural school. International Journal of Advanced Research, 3(2), 788-794.

Pathania, R., \& Chopra, G. (2017). Enhancement in life skills of adolescent girls through intervention. Studies on Home and Community Science, 11(1), 29-31. https://doi.org/10.1080/0973718 9.2017.1351073

Population Council. (2012). Sexuality education: A ten-country review of school curricula in East and Southern Africa. Regional Report. UNESCO \& UNFPA.

Prasad, D. S. (2009). Effect of life skills-based health education on adolescent students' awareness of and attitude toward substance use [Unpublished master's thesis]. Indian Institute of Technology. http://eprint.iitd.ac.in/bitstream/handle/12345678/5812/TH-3930.pdf?sequence=2

Refahi, Z. (2008). Life skills training as a prevention strategy for adolescent social psychopaths. Journal of New Approach in Educational Administration, 1(2), 135-151. https://www.sid.ir/en/ journal/ViewPaper.aspx?ID=184654

Robeyns, I. (2017). Wellbeing, freedom and social justice: The capability approach re-examined. Open Book Publishers. https://doi.org/10.11647/OBP.0130

Sahebalzamani, M., Moraveji, M., Farahani, M., \& Feizi, F. (2013). Investigation the effect of life skills training on students' emotional reactions. Journal of Applied Environment and Biological Sciences, 3(9), 134-137.

Sahni, U. (2017, September 13). Reframing girls' education in India. Education plus development, Brookings. https://www.brookings.edu/blog/education-plus-development/2017/09/13/ reframing-girls-education-in-india/

Sayed, Y., \& Ahmed, R. (2015). Education quality, and teaching and learning in the post-2015 education agenda. International Journal of Educational Development, 40, 330-338. https:// doi.org/10.1016/j.ijedudev.2014.11.005

Schurer, S. (2017). Does education strengthen the life skills of adolescents? IZA World of Labor. https://doi.org/10.15185/izawol.366

Shaiju, P., \& Rages, J. (2018). Impact of edutainment programme in developing life skills with specific reference to critical and creative thinking among adolescent students of Chattisgarh State. Artha-Journal of Social Sciences, 17(1), 9-22. https://doi.org/10.12724/ajss.44.2

Shapiro, L. (2007). The embodied cognition research programme. Philosophy Compass, 2(2), 338-346.

Sreehari, R., Varghese, J., \& Thomas, J. R. (2018). Effect of life skills training on fear of negative evaluation and self-image among school adolescents. Indian Journal of Positive Psychology, 9(1), 193-195. https://doi.org/10.15614/ijpp.v9i01.11771

Srikala, B., \& Kishore, K. K. (2010). Empowering adolescents with life skills education in schools - School mental health program: Does it work? Indian Journal of Psychiatry, 52(4), 344-349. https://doi.org/10.4103/0019-5545.74310

Subasree, R. (2012). Promoting personal profile of adolescents through life skills training programme. Indian Journal of Positive Psychology, 3(3), 224-228.

Swales, J. (1990). Genre analysis: English in academic and research settings (1st ed.). Cambridge University Press.

Taylor, A. (2005). What employers look for: The skills debate and the fit with youth perceptions. Journal of Education and Work, 18(2), 201-218. https://doi.org/10.1080/13639080500085984 
Tikly, L., \& Barrett, A. M. (2011). Social justice, capabilities and the quality of education in low income countries. International Journal of Educational Development, 31(1), 3-14. https://doi. org/10.1016/j.ijedudev.2010.06.001

UNICEF. (2010). Basic education and gender equality: Quality of education. https://www.unicef. org/education/index_quality.html

Vishwas, M., \& Hussain, M. (2014). Empowerment of adolescent girls for reproductive health base. Human Rights International Research Journal, 2(1), 84-88.

Waithima, C. W. (2017). Life skills enhancement for psychoactive substance use reduction among school going adolescents in Kenya. PEOPLE: International Journal of Social Sciences, 3(2), 2000-2014. https://doi.org/10.20319/pijss.2017.32.20002014

Walker, M. (2012). A capital or capabilities education narrative in a world of staggering inequalities? International Journal of Educational Development, 32(3), 384-393. https://doi. org/10.1016/j.ijedudev.2011.09.003

Westera, W. (2011). On the changing nature of learning context: Anticipating the virtual extensions of the world. Educational Technology \& Society, 14(2), 201-212.

Winterton, J., Delamare, F., \& Stringfellow, E. (2006). Typology of knowledge, skills and competences: Clarification of the concept and prototype. Office for Official Publications of the European Communities.

Winthrop, R., \& McGivney, E. (2016). Skills for a changing world: Advancing quality learning for vibrant societies. Center for Universal Education at Brookings.

World Bank. (2018). Learning to realize education's promise. World Development Report.

Yankah, E., \& Aggleton, P. (2008). Effects and effectiveness of life skills education for HIV prevention in young people. AIDS Education and Prevention, 20(6), 465-485. https://doi. org/10.1521/aeap.2008.20.6.465

Yankey, T., \& Biswas, U. N. (2012). Life skills training as an effective intervention strategy to reduce stress among Tibetan refugee adolescents. Journal of Refugee Studies, 25(4), 514-536. https://doi.org/10.1093/jrs/fer056

Open Access This chapter is licensed under the terms of the Creative Commons Attribution 4.0 International License (http://creativecommons.org/licenses/by/4.0/), which permits use, sharing, adaptation, distribution and reproduction in any medium or format, as long as you give appropriate credit to the original author(s) and the source, provide a link to the Creative Commons license and indicate if changes were made.

The images or other third party material in this chapter are included in the chapter's Creative Commons license, unless indicated otherwise in a credit line to the material. If material is not included in the chapter's Creative Commons license and your intended use is not permitted by statutory regulation or exceeds the permitted use, you will need to obtain permission directly from the copyright holder. 